\title{
投影変換アルゴリズムの評価
}

\section{Evaluation of Map Projection Converting Algorithms}

\author{
飯倉 善和* \\ Yoshikazu IIKURA
}

\begin{abstract}
Absiract : In digital maps, positions are usually given by latitude and longitude, while topographic maps and satellite images are projected on the UTM coordinate system. In order to overlay them, the map projections should be converted each other. In this report, we investigate error factors of the conversion and evaluate their accuracy. Based on these analysis, we propose a practical algorithm, of which accuracy is enough for the conversion of the topographic maps and satellite images.
\end{abstract}

\section{1.はじめに}

国土地理院などから発行される数值地図情報の多く (標高50mメッシュ，海岸線\&行政界ベクターなど)は 緯度と経度を基本とする座標（経緯度座標）で与えら れている11。一方，地形図や衛星画像など 2 次元平面へ の投影が必要な場合には，ガウス・クリューゲル図法 に基づく座標系(UTM 座標など) が用いられる。した がって，これらの情報を重ね合わせるためには，2つ の座標系の相互の変換が必要となる。

ガウス・クリューゲル困法における経緯度座標の 2 次元平面への投影については数学的な解析に基づく級 数解が知られており，理論的には誤差のない計算が可 能である2)。しかし，実用的には計算量と計算誤差を勘 案した級数解の打ち切りが必要となる。2 万 5 千分の 1 の地形図に基づいた多くの数值デー夕の場合，位置 は $10 \mathrm{~m}$, 標高は $5 \mathrm{~m}$ 程度の精度しか保証されていな

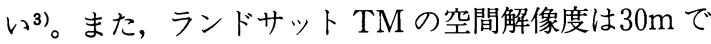
ある。このような画像デー夕との重ね合わせにはどの

*弘前大学知能機械システム工学科

Dept. Intelligent Machines and System Engineering,

Hirosaki University

T036-8561 弘前市文京町 3 番地

3 Bunkyo-cho, Hirosaki, 036-8561 Japan

「写真測量とリモートセンシング」VOL. 39，NO.3， 2000
程度の変換式が必要なのであろうか。

数值地図ユーザーズガイド（以下ガイドと省略す る) ${ }^{1} に は$ 経緯度座標から UTM 座標へ変換するプロ グラム (FORTRAN) が掲載されている。またガイド の最新版の参考資料に紹介されている計算式に従えば 逆変換のプログラムの作成も可能である。これらの変 換式の精度は，より高次の変換式 ${ }^{2)}$ と比較することで $0.1 \mathrm{~mm}$ 以内に納まることが確認できる。

本報告では，投影変換における䛊差要因とその大き さを具体的に評価するとともに, 衛星画像や地理情報 の処理のための変換アルゴリズムを検討する。第 2 節 では，測地系やガウス・クリューゲル図法など投影変 換に必要な基本的な概念を紹介する。第 3 節では数值 計算における誤差要因を考える。第 4 節では, 変換ア ルゴリズムで重要な問題となる子午線弧長の計算方法 について検討する。第 5 節では経緯度から UTM への 相互変換式とその精度を評価する。第 6 節では計算の 効率化を検討する。第 7 節はまとめである。

\section{2. 基本的な概念と用語}

\section{2-1 測 地 系}

地球の形が回転棈円体に非常に似た形をしているこ とは18世紀以降よく知られている2)。また，回転楕円体 は数学的な取扱いも容易であるため, ガウス・クリュー ゲル図法を始め多くの投影法で用いられている。我が 
国では，ベッセルが示した值をもとに測量法(第11条) により，赤道半径 $\mathrm{a}$ と扁平率 $\mathrm{f}$ が以下のように定義さ れている。

赤道半径： $6,377,397.155 \mathrm{~m}$

扁平率: $1 / 299.152813$

\section{2-2ガウス・クリューゲル図法}

ガウス・クリューゲル図法は横メルカトール困法と も呼ばれる。回転楕们体を门筒に投影した心射円柱闵 法と混同されることが多いが，等角性を保証するため に複素関数論を用いた厳密な取扱いが必要である。変 換式を導出するには複素平面上に以下の解析関数 $f$ を考える2),4

$i x+y=f(\phi+i \Delta \lambda)$

ここて， $x, y$ を平面座標， $\phi, \Delta \lambda$ を緯度抄よび中央経 線と経度差とするにここで $x$ 軸在虚数軸としたことに 注意)。縮尺を中央経線上で正しくするためには，次の 式が成立しなけ机ばならない。

$y=f(\phi)=S_{\phi}$

$S_{\phi}$ は赤道から緯度 $\phi$ までの経線の長さ（子午線弧長） であり，次の式で定義される。

$S_{\phi}=\int_{0}^{\phi} R d \phi$

ただし，子午線曲率半径 $R$ は $a$ を赤道半径, $e^{2}$ を離心 率として次のように表せる。

$R=\frac{a\left(1-e^{2}\right)}{\sqrt{\left(1-e^{2} \sin ^{2} \phi\right)^{3}}}$

(1)式の中央経線の周りのテーラー展開における微係数 を(3)式の関係式から逐次的に求めることにより，解を 級数の形で求めることができる。なお，実際の計算で は操作を簡単にするために緯度ではなく次の式で定義 される異性緯度 $q$ が用いられる。

$d q=\frac{R}{N \cos \phi} d \phi$

ただし, 卯西線曲率半径 $N$ は次のように表せる。

$N=a / \sqrt{\left(1-e^{2} \sin ^{2} \phi\right)}$

$x y$ 座標系から緯度経度への逆変換では, 縦軸の座標 值から次の式で定義される垂足緯度 $\phi_{1}$ (図 1 参照) が 用いられる。

$y=\int_{0}^{\phi_{1}} R d \phi$

ここで，与えられた $y$ 座標值にたいして垂足緯度 $\phi_{1}$ が積分の範囲として定義されている。な㧍，数值標高

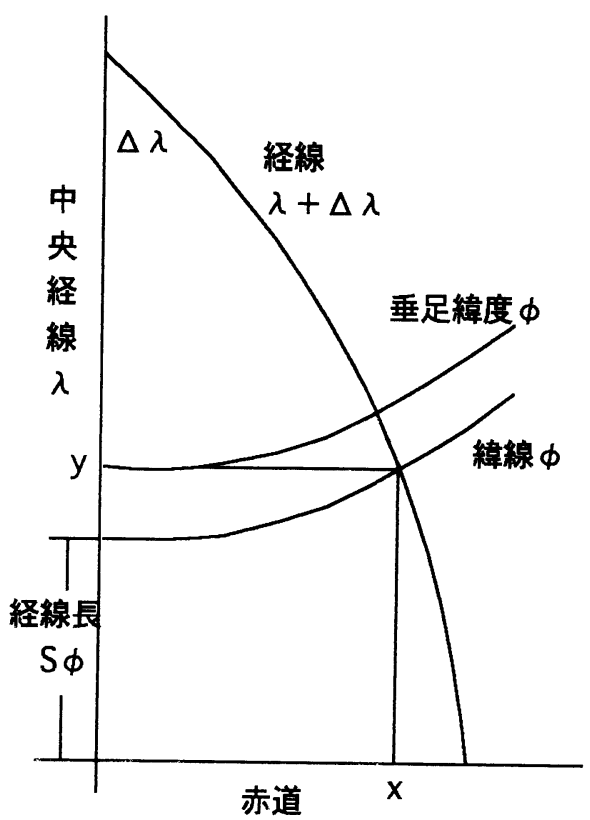

図 1 UTM 座表系上の経緯線

モデルなどのラスター-データの投影変換では再配列に おいて逆変換が必要になることにも注意されたい。

\section{2-3 UTM 座標系}

UTM 座標系は地球全体を経度 6 度每に60の带 (Zone)にわけ，その帯の中央の子午線を中央経線 $\lambda$ と して，その帯内をガウス・クリューゲル図法で横円筒 に投影したものである4)。ゾーン内での平均的な歪み が小さくなるように，ガウス・クリューゲル図法での 平面座標 $(\mathrm{x}, \mathrm{y})$ に対して, UTM 座標 $(\mathrm{X}, \mathrm{Y})$ は以 下のように調整される。

$\mathrm{X}=0.9996 \mathrm{x}+500000$

$\mathrm{Y}=0.9996 \mathrm{y}$

我が国はゾーンの51～55に位置する。

より高い精度の座標系として我が国では平面直角座 標系が大縮尺の地図に用いられている。UTM 座標系 と同様にがウス・クリューゲル困法を用いているが, 縮尺率（0.9999）と原点のとり方が異なる。

\section{3. 誤差要因}

数值計算においては, 丸め誤差，打ち切り誤差およ び各種の近似方式が問題となる5)。また，投影変換では 地球の形に関する各種の定数の取扱いにも注意を要す 
る。

測地学では最新の計測技術を用いて地球の形のより 厳密な值を追求しているが，実用上は，種々の整合性 を考えて測量法で定められた赤道半径と扁平率で一意 に定められた回転棈円体を用いるべきである。これら の定数を実数值として考えれば有効数字は無限大であ る。しかし，支献によって(12),4),6極半径や離心率など の) 2 義的なパラメータが示されている場合も多く, こ れらに関する值については必ずしも統一されているわ けではない。例えば，ガウス・クリューゲル図法の計

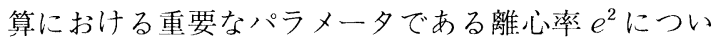
ても，定義に基づいて倍精度で計算した値と一般に使 われる值 ${ }^{1)}$ では小数点以下 11 桁以降が以下のように異 なっている。

定義に基づく離心率 $\quad: 0.006674372227347$

一一般に使われている值：0.0066743722231315

離心率が $\left(1-e^{2}\right)$ の形で使われることを考えると, こ の違いは倍精度の計算における丸女䛊差程度の大きさ であり，通常の計算においては問題とならない。

経緯度座標の UTM 座標への変換および逆変換の 理論的な級数解に拉いて，どの次数で級数を打ち切る かによって誤差が発生する。子午線弧長の計算を含め た投影変換における䛊差については，4節以降で詳し く検討するが，国土地理院の変換式を倍精度で計算す れば，打ち切り䛊差に関しては有効数字で 9 〜 10 桁,

物理的な長さとして $0.1 \mathrm{~mm}$ 程度に押さえることが可 能である。

次に入力デー夕に含まれる䛊差を検討する。地形四 に表示した対象物の平面位置の精度は写真測量の基準 になった点の誤差はないものとして地上での明瞭な地 点の $60 \%$ 以上を図上 0.5 ミリ以内, 残りの $20 \%$ 以上も図 上で最大 1.5 ミリ以内に入ることになっている ${ }^{3)}$ 。 2 万 5 千分の 1 の地形図の場合, 約 $10 \mathrm{~m}$ と考えてもよいで あろう。また, 標高点と等高線の高さの精度は, それ ぞれ $2.5 \mathrm{~m}$ と $5 \mathrm{~m}$ となる。

地形困から数值デー夕を読み取る場合にも䛊差が発 生する。人間でも $300 \mathrm{dpi}$ のスキャナーでも約 0.1 ミリ 程度, 2 万 5 千分の 1 の地形困の場合で $2.5 \mathrm{~m}$ の読み 取り誤差である。さらに, UTM 座標系における縮尺が ゾーンの端で $0.04 \%$ 歪むこと $(10 \mathrm{~km}$ で $4 \mathrm{~m})$, 地形困 の紙の歪みなどによる制御点のズレ等も考えられる。

これまでの衛星画像の空間分解能は数 $10 \mathrm{~m}$ (ランド サットTM やスポット HRV) であったが，今後は1 $\mathrm{m}$ 程度に改善されてくる。これらの画像を正射投影を 含む精密幾何補正を行うことにより, 平均的には 1 画 素以内の幾何的な精度が期待できる7)。

以上の考察から地形図や衛星画像の幾何的な精度は $1 \mathrm{~m} \sim 10 \mathrm{~m}$ 程度であり，投影変換には $10 \%$ 程度の䛊差 $(10 \mathrm{~cm} \sim 1 \mathrm{~m})$ は許されると考えられる。

\section{4. 子午線弧長の計算}

変換式の計算には, 赤道から対象とする地点（緯度 ф) までの子午線弧長を求女る必要がある(四 1 参照)。 子午線弧長は積分で定義されるが，数值計算では以下 の近似式を用いるのが効率的である。

$$
\begin{aligned}
S_{\phi}= & a\left(1-e^{2}\right)\left(A_{0} \phi-\frac{1}{2} A_{1} \sin 2 \phi+\frac{1}{4} A_{2} \sin 4 \phi\right. \\
& -\frac{1}{6} A_{3} \sin 6 \phi+\frac{1}{8} A_{4} \sin 8 \phi-\frac{1}{10} A_{5} \sin 10 \phi
\end{aligned}
$$

ここで, 係数 $A_{i}$ は離心率の関数として与えられる が6),8), ベッセルの地球棈円体に対してはあらかじめ計 算された以下の值が利用できる11。

$$
\begin{aligned}
& A_{0}=1.005037306048555 \\
& A_{1}=0.005 \quad 047849240300 \\
& A_{2}=0.000 \quad 010563786831 \\
& A_{3}=0.000 \quad 000 \quad 020633322 \\
& A_{4}=0.000 \quad 000 \quad 000038853 \\
& A_{5}=0.000000000000070
\end{aligned}
$$

(9)式で計算した值とシンプソン法を用いて(3)式の積分 を計算した結果との差は倍精度の計算における丸女誤 差程度（約 $1 \mu \mathrm{m}$ ) であった。

$A_{2}$ から $A_{5}$ の各項による寄与を計算し結果を図 2

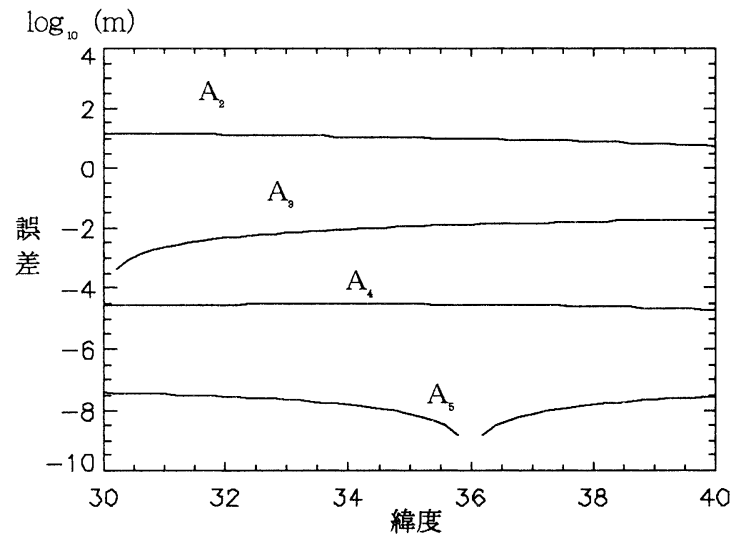

図 2 近似式による子午線弧長の計算誤差 
に示す。経度は歪みが最も大きくなるゾーンの境界(東 経144度)とし，緯度を北緯30度から40度まで変化させ た。 $A_{4}$ の項による寄与は $0.1 \mathrm{~mm}$ 以下, $A_{3}$ の項による 寄与は $2 \mathrm{~cm}$ 以下であり, 高い精度が要求されない場 合には省略が可能である。

UTM 座標から経緯度座標を求めるには，子午線弧 長の逆計算，すなわち，与えられた子午線長に対して いわゆる垂足緯度が必要となる。がイド1には経線長 $S_{\phi}$ の逆関数を逐次近似法 (ニュートン法) で反復計算 する方法が示されている。日本付近では初期值を35度 とすると，3 回程度の反復計算を行うことにより約 $10^{-9}$ 度の精度で垂足緯度を求めることができるとされ ている1)。しかし，反復計算などが必要とならない以下 の近似式により，数值計算を簡明かつ効率的に行うこ とができる。

$\phi_{1}=u+\sum_{n=1}^{5} C_{n} \sin 2 n u$

ただし

$u=\frac{y}{a\left(1-e^{2}\right) C_{0}}$

文献9に示された式の誤りに注意されたい。係数 $C_{i}$ は ベッセルの地球棈円体に対して以下のように示されて いるが9，原典は明らかではない。

$$
\begin{aligned}
& C_{0}=1.005037306045577 \\
& C_{1}=0.002511273240647 \\
& C_{2}=0.000 \quad 003 \quad 678785849 \\
& C_{3}=0.000000007380969 \\
& C_{4}=0.000000000016832 \\
& C_{5}=0.000 \quad 000 \quad 000000041
\end{aligned}
$$

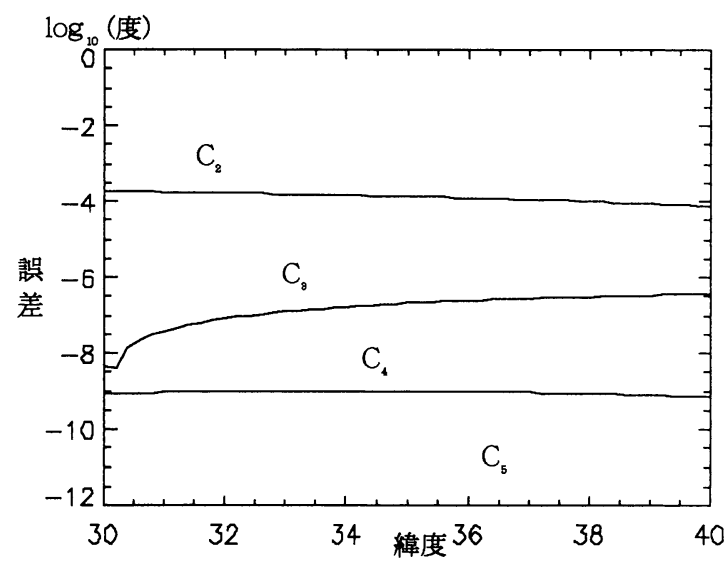

図３＼cjkstart近似式による子午線弧長の逆計算誤差
(9)式で変換した子午線弧長を，この近似式(10)を用いて 緯度に変換し，最初の設定値との差を評価した。図 3 に示すように $C_{3}$ の項による寄与は約 0.0000003 度（5 $\mathrm{cm} ）$ 以下であり，省略が可能である。

\section{5 . 投影の変換}

本節ではガイドの変換式1に対して，より低次の変 換式を使用することを提案し，その誤差を評価する。

\section{1 経緯度から UTM 座標への変換}

はじめに変換式に用いる変数を紹介する。赤道半径 $a$, 離心率 $e^{2}$, 曲率 $R$, 卯西線曲率半径 $N$ については 第 2 節で述べた。経緯度 $(\lambda, \phi)$ から $x y$ 座標系への変 換では

$\rho=\frac{180}{\pi}:$ 度とラディアンの変換係数

$t=\cos \phi, \quad \eta^{2}=\frac{e^{2}}{1-e^{2}} \cos ^{2} \phi$

がさらに必要になる。

提案する変換式を以下に示す。

$x=\frac{N \Delta \lambda}{\rho} \cos \varphi+\frac{N \Delta \lambda^{3}}{6 \rho^{3}} \cos ^{3} \varphi\left(1-t^{2}+\eta^{2}\right)$

$y=S_{\phi}+\frac{N \Delta \lambda^{2}}{2 \rho^{2}} \sin \varphi \cos \varphi+\frac{N \Delta \lambda^{4}}{24 \rho^{4}} \sin \varphi \cos ^{3} \varphi\left(5-t^{2}\right)(13 \mathrm{~b})$

図 4 に東経144度における打ち切り誤差を示した。提案 する変換式は, ガイドの変換式の最高次の項などを省 略したものであるが, 北緯 30 度から 40 度の範囲で $x$ 座 標， $y$ 座標とも打ち切り誤差が $5 \mathrm{~cm}$ 以内に納まって

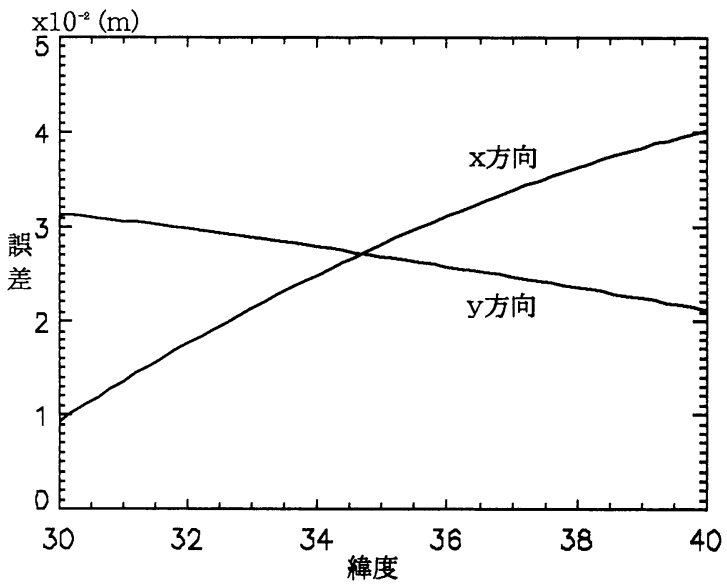

図 4 提案する变換式の打きり誤差 
いる。

\section{$5.2 x \boldsymbol{y}$ 座標から緯度経度への变換}

$x y$ 座標から緯度経度への変換では図 1 に示す垂足 緯度が用いられるため, 添字の 1 で変換の場合と区別 する。

$R_{1}=\frac{a\left(1-e^{2}\right)}{\sqrt{\left(1-e^{2} \sin ^{2} \phi_{1}\right)^{3}}}$

$N_{1}=a / \sqrt{\left(1-e^{2} \sin ^{2} \phi_{1}\right)}$

$t_{1}=\cos \phi_{1}, \quad \eta_{1}^{2}=\frac{e^{2}}{1-e^{2}} \cos ^{2} \phi_{1}$

提案する逆変換の計算式を以下に示す。

$$
\begin{aligned}
\frac{\Delta \lambda}{\rho \sec \phi_{1}}= & \frac{x}{N_{1}}-\frac{1}{6}\left(\frac{x}{N_{1}}\right)^{3}\left(1+2 t_{1}^{2}+\eta_{1}^{2}\right) \\
& +\frac{1}{120}\left(\frac{x}{N_{1}}\right)^{5}\left(5+28 t_{1}^{2}\right)
\end{aligned}
$$

$\frac{\phi}{N_{1} \rho t_{1}}=\frac{\phi_{1}}{N_{1} \rho t_{1}}-\frac{1}{2 R_{1}}\left(\frac{x}{N_{1}}\right)^{2}+\frac{1}{24 R_{1}}\left(\frac{x}{N_{1}}\right)^{4}\left(5+3 t_{1}^{2}\right)(15 \mathrm{~b})$

図 5 にゾーンの境界 $(x=760000 \mathrm{~m})$ における打ち切 り誤差を図 4 の緯度の範囲にほぼ相当する座標值につ いて計算した結果を示した。 $10^{-7}$ 度は約 $1 \mathrm{~cm}$ に相当 することから，提案する変換式により約 $10 \mathrm{~cm}$ の精度 が保証される。(15a)式ではガイドの変換式で以下の 項(16)を省略しただけであるが，緯度方向に較べて経度 方向の誤差が大きくあらわれている。

$\frac{1}{120}\left(\frac{x}{N_{1}}\right)^{5} 24 t_{1}^{4}$

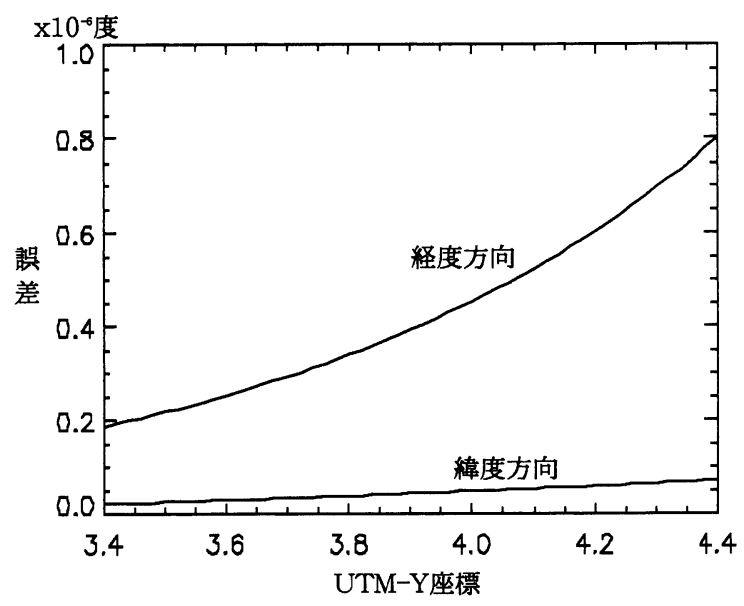

図 5 提案する逆变換式の打きり誤差

\section{6. 計算の効率化}

前節で簡便な変換式を提案したが，ここではその計 算量を国土地理院の変換式と比較する。その前に多項 式の計算を効率化するためのいくつかの手法を紹介す る。なおアルゴリズムの実装には対話的な処理が可能 で，豊富な表示解析機能をもついわゆる第 4 世代言語 である IDL (Interactive Data Language）を用いた。

(1) 定数の大域的な宣言

$a, e^{2}, \rho, A_{i}, C_{i}$ などの定数だけでなく, $a\left(1-e^{2}\right)$ や $e^{2} /\left(1-e^{2}\right)$ などもあらかじめ計算して大域変数と して宣言した。サブルーチンの中の静的な内部変数と しても設定しても良い。

(2) 繰り返し計算の除外

三角関数 $\cos \phi, \Delta \lambda / \rho, x / N_{1}$ などは重複して計算する ことのないように(12)式や(14)式で示すような新たな変数 とした。

(3) ホーナーの算法

多項式の計算にはホーナーの算法を用いた。提案す る変換式では $(15 \mathrm{a})$ 式以外には，その効果は小さいが, 国土地理院の変換式では非常に有効である。

以上の対策を踏まえて変換式のプログラムを作成し 処理時間を調べた。その結果，提案するアルゴリズム は国土地理院のアルゴリズムに較べて経緯度から UTM 座標への変換で $71 \%$, UTM 座標から経緯度へ の変換で46\%の処理時間を要した。逆変換での処理効 率がよいのは，子午線弧長の逆計算にニュートン法に よる反復計算を行わないということが大きく影響して いる。

\section{7.おわりに}

地理的な数值情報の多くは経緯度座標系に基づいて いるのに対して，地形図や衛星画像は UTM 座標系を 用いている。これらを重ねあうために必要となる実用 的な投影変換アルゴリズムは，計算量と計算誤差を勘 案してきめられるべきである。本報告では，投影変換 の数值計算における丸め誤差，打ち切り誤差および各 種の近似方式などの誤差要因とその大きさを具体的に 検討した。この解析に基づいて, 数 $10 \mathrm{~cm} の$ 誤差が許さ れる地形図や衛星画像における位置情報を大力デー夕 とした場合の実用的な変換アルゴリズムを提案した。 
衛星画像の実利用を考えた場合, 各種主題図や数值 標高モデルなどと重ね合わせることにより大きな付加 価值が生まれることが期待される6,10) しかし, 衛星画 像処理の分野では，投影変換や幾何的な精度といった 測量における基本的な概念に対する関心が高いとはい 之ない。例之ば, 衛星画像処理のテキスト ${ }^{11} に は$ 経緯度 から UTM 座標系への変換式が紹介されているが，実 際にプログラムを作成するための情報としては不十分 である。また，子午線弧長の逆計算などの具体的なう 法を紹介した文献は極めて少ない8)。

一方，測量の分野では計算アルゴリズムやその効率 性に関する関心が低いように思われる。アルゴリズム の効率は衛星画像や数值標高モデルなど大量のデータ 処理が必要となる場合には重要な問題となることを指 摘したい。

衛星画像処理と測量をつなげる意味で本学会の役割 には大きな期待が寄せられている。本報告に対して多 くのカの御意見をいただけることを期待するととも に，この種の問題への関心が高まれば幸いである。

（受付日2000.3.14，受理日2000.5.11）

\section{引用文献}

1) 国土地理院監修，数值地図ユーザーズガイド（第
2 版補訂版)，日本地図センター，1998

2）野村正七，地図投影法，日本地図センター，1983

3 ) 大竹一彦, 2 万五千分の一地図, 古今書院, 1990

4) 春日屋伸昌, 測量学 I, 朝倉書店, 1978

5 ）宇宙開発事業団監修，地球観測デー夕利用ハンド ブックーランドサット編・改訂版一，リモートセン シング技術センター， 1986

6 ）飯倉善和，横山隆三，ランドサット TM 画像の正 射投影とその評価, 写真測量とリモートセンシング, Vol. 37, No. 4, pp. 12-22, 1998

7 ) 原田健久，わかりやすい測量厳密計算法，鹿島出 版会, 1992

8 ）坪川家恒，須川 力，測量の数学的基礎，現代測 量学第 1 巻, 日本測量協会, 1981

9 ) 伊理正夫, 藤野和建, 数值計算の常識, 共立出版, 1985

10）飯倉善和，横山隆三，ランドサット TM 画像の大 気抒よび地形効果の補正，日本リモートセンシング 学会誌, Vol.19, No.1, pp.2-16, 1999

11）高木幹雄, 下田監修, 画像解析ハンドブック, 東 京大学出版会, 1991 